\title{
The Trend of Language Use among Netizens in Instagram “aslisuroboyo” Account
}

\author{
Slamet Setiawan \\ Universitas Negeri Surabaya \\ Surabaya, Indonesia \\ slametsetiawan@unesa.ac.id
}

\author{
Fatma Rahayu Nita \\ Universitas Negeri Surabaya \\ Surabaya, Indonesia \\ fatmanita@mhs.unesa.ac.id
}

\begin{abstract}
In multilingual communities, Surabaya-Indonesia is one of them, people commonly use at least two languages, indigenous and national languages. Due to the Javanese is the greatest ethnic group in Surabaya and Javanese is the most spoken, people still use Javanese language to communicate. However, an interesting phenomenon is detected in Instagram of "aslisuroboyo" account. Surprisingly, English is also frequently used by Netizens. Thus, this study tries to reveal the dominant language use and the reasons for the use of English in this account. Using netnography and virtual interview, the data were obtained. The results show that the Javanese was mostly used. However, the netizens were detected to use the English as well in the form of code- mixing. It is also revealed that women had a tendency to mix their languages while men did not. Some Javanese informants confessed that the use of English is for gaining prestige. This may suggest that the Javanese language has been losing its power to boost its users' self-esteem in globaldigital communication particularly in its written mode. Tactful instruction of the Javanese language should be made in order that this indigenous language can win the floor in written communication for its speakers.
\end{abstract}

Keywords-language use; code mixing \& switching; prestige; indigenous language

\section{INTRODUCTION}

One of the newest social media in the world is Instagram, a mobile app that allows users to capture and share images and videos with followers [1]. Despite its popularity, many people in Indonesia use Instagram as a means of modern medium of communication.

Among the mushrooming emergence of Instagram account, the use of language in "aslisuroboyo" account is interesting to investigate. At least there are four points to support the claim. This account is popular in Surabaya, East Java. The main purpose of this account is to update all the information that is related to Surabaya, for instance, popular culinary, big events, and tourism resorts. This account is different from any other account because the netizens do not only concern with cultural identity as Javanese society but also still use the ethnic language, Javanese. In addition, the netizens of this account are mostly young Surabayanese notably whose dominant language is Javanese.

Many researches have been done to reveal the use of English by non-native speakers, among others are the use of language among youth in Kazakhstan [2]; language choice, code switching, and code mixing in Biase [3]; and identity and language choice in South African [4]. The findings generally show that non-native speakers use English language more than their own native language. This entails that English becomes their dominant language. The reasons of this trend are as a means of constructing identity and gaining prestige. In addition, the study on language use in Facebook shows that English is the Facebookers' dominant language. Their reason is that English is globally used in social media and they want to make a better understanding the posts made by other netizens [5].

Unlike the previous studies, this one was triggered by the initial language phenomenon that was found among netizens' comments in Instagram of "aslisuroboyo" account. As its name of the account, this was created from, by, and for Javanese people as the medium to preserve the Javanese heritage, including the Javanese language; yet, English was frequently used. Therefore, this study tries to reveal: 1) What is the dominant language in the netizens' comments? 2) What is the structure of their language? 3) What are the reasons for their use of English in their comments? 4) Is there any different language use between male and female?

\section{METHOD}

As this study investigates the use of written language on Instagram of "aslisuroboyo" account. The qualitative method was employed by conducting the combination of Netnography and virtual individual interview. The former is used to analyse people's social activities and confronts onto the internet and throughout other technologically mediated communications to find recent uses of social media for communities [5]. Whereas the former is done to seek deeper netizens' underlying reasons why they used English in the account of Javanese community.

The data were collected from November to December 2017 involving 58 netizens, 34 of them are females and 24 are 
males. Of the total respondents, 21 netizens were frequently used English in their comments. Therefore, they were contacted for the virtual interview.

\section{RESULT AND DISCUSSION}

\section{A. The Dominant Language of "aslisuroboyo" Account}

The followers of "aslisuroboyo" account are mainly Surabayanese. As predicted, from 34 netizens, the dominant language used in this account is Javanese as it is widely spoken in Surabaya (70.59\%). Other languages used consecutively from the greater to the lesser are Indonesian $(17.65 \%)$ and English (11.76\%). Thus, the netizens used Javanese as their ethnic language, Indonesian as their national language, and English as their foreign and international language. The underlying reasons, particularly, for using English in the netizens' post are presented in section D.

(01)

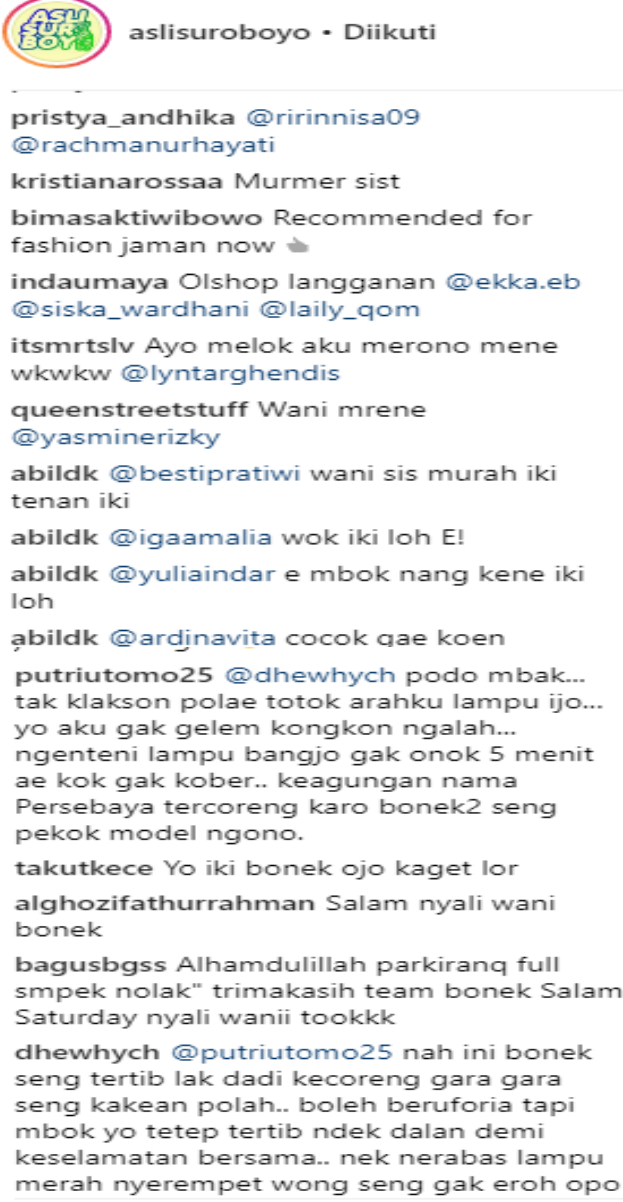

aslisuroboyo - Diikuti

pristya_andhika@ririnnisaO9

@rachmanurhayati

kristianarossaa Murmer sist

bimasaktiwibowo Recommended for fashion jaman now $\Rightarrow$

indaumaya Olshop langganan @ekka.eb

@siska_wardhani@laily_qom

itsmrtslv Ayo melok aku merono mene

wkwkw@lyntarghendis

queenstreetstuff Wani mrene

@yasminerizky

abildk@bestipratiwi wani sis murah iki

tenan iki

abildk@igaamaliawokiki loh E!

abildk@yuliaindare mboknang kene iki

loh

abildk@ardinavita cocok qae koen

putriutomo25@dhewhych podo mbak... tak klakson polae totok arahku lampu ijo... yo aku gak gelem kongkon ngalah... ngenteni lampu bangjo gak onok 5 menit ae kok gak kober.. keagungan nama Persebaya tercoreng karo bonek2 seng pekok model ngono.

takutkece Yo iki bonek ojo kaget lor

alghozifathurrahman Salam nyali wani bonek

bagusbgss Alhamdulillah parkiranq full smpek nolak" trimakasih team bonek Salam Saturday nyali wanii tookkk

dhewhych@putriutomo25 nah ini bonek seng tertib lak dadi kecoreng gara gara seng kakean polah.. boleh beruforia tapi mbok yo tetep tertib ndek dalan demi keselamatan bersama.. nek nerabas lampu merah nyerempet wong seng gak eroh opo

Fig.1. The Evidence of Javanese Language in Instagram

It is good evidence that the Javanese language is still mostly favoured by young netizens in this Instagram account. The example of comments with Javanese as dominant language is presented in (01). The data shows that almost all netizens used Javanese in their posts. Some of the netizens wrote long comments in the account. This indicates that their Javanese proficiency is presumably high. A few English words are found. The first netizen used 'sist' or 'sis' which stands for sister in English. She continued using English: Recommended for fashion, now. Other English words used by other netizens in this excerpt (01) are queen street stuff, team, olshop (online shop), parking full, and Saturday. Similarly, a few Indonesian words are found. They are nama 'name', tercoreng 'get bad label', keselamatan 'for safety', and terima kasih 'thank you'.

Note to be made that as this account's name is "aslisuroboyo", Javanese used among netizens is JavaneseSurabaya dialect. The distinguished words which are from the standard ones are koen 'you', totok 'from', bonek stands for bondo nekat 'No money does not matter, it needs a gut to get something'. Another feature of this dialect is the use of the harsh expression. It is common to use "f" word in Surabaya for many purposes but it is not found in this excerpt. However, there is a sarcastic word to describe some one's stupidity, pekok.

\section{B. Evidence of being bilingual and multilingual netizens}

When the closer attention is taken, the netizens did not use those three languages 'monolingually' but some of them used mix languages. Thus, different language patterns practiced by 24 netizens in Instagram are detected, namely: mix JavaneseIndonesian (12,5\%), mix Javanese-English (45,8\%), mix Indonesian-English (25\%), and mix Javanese-Indonesian English (16,6\%). This phenomenon is an example of the bilingual and multilingual practice of language use in social media.

The following is the examples of the bilingual and multilingual practices in the Instagram account. Note: For consistency, writing convention is made that Javanese words are in Italic, Indonesian words are in the bold case, whereas English is in the normal case.

There are netizens' comments that were written in mix Javanese-Indonesian. An example is in (02) whereby there is one inserted Indonesian word sesuai 'adjust' literally but 'consider' contextually. The remaining words are all in Javanese. However, there is an interesting phenomenon that one word is constructed by two languages. The base is in Indonesian whereas the suffix is in Javanese. The word sesuai should take -kan when it is fully Indonesian. But the netizen used $-n o$, Javanese suffix. The Indonesian insertion into Javanese construction takes place in the initial sentence.

(02) Sesuaino karo dompetmu pisan cak:v ojok angger2 mrunu.

'Consider the money you have made, don't go there any Time as you like.'

The mix Javanese-English is detected from the account, as in (03). The first part is Javanese and the last part is English.

(03) Kok isok ngunu, unbelievable.

'How come, unbelievable.'

Another pattern is mix Indonesian-English as in (04). In this mix, the English word 'hunting' is inserted in the middle of the Indonesian sentence. 
(04) Jadi kapan hunting kemari.

'When will we do hunting here.'

The interesting phenomenon of mix language pattern in "aslisuroboyo" account is the use of three languages of Javanese-Indonesian-English. Study the data in (05).

(05) Iniloh te yang ndek dalan Kenjeran, nek udah release ауо тrипи.

I found one on Kenjeran Street, when it has been released, let's go there.'

The netizen wrote the comment in three languages in one sentence as in (05). S/He used pattern of the sentence in Javanese-Indonesian-English-Javanese/Indonesian. The only English word inserted is 'released'.

The finding may suggest that some of the netizens of "aslisuroboyo" account are bilinguals and multilinguals. This can be seen from the way they communicated with each other. They apply different strategies in using their languages to present their idea in written mode. They can use mix language patterns as a result of the possible mixtures of Javanese, Indonesian, and English languages. What levels are the netizens' mix language? The detailed answer to this question is addressed in section $\mathrm{C}$.

In the past, Surabaya people' communication is limited to their neighbors and their social network. In this digital era, however, their communication is not limited. Social media application including Instragram creates new advanced world communication. The use of the same mutual intelligible language is an obligatory medium unless the message is not comprehensible to receivers. The Instagram of "aslisuroboyo" account is an example.

This account which is claimed to be the icon of Javanese ethnicity in Surabaya accommodates their netizens to build communication. The finding indicates that Javanese is still their dominant language. This is reasonable that Javanese is still mostly spoken language in the community. This claim is based on 1971 census that the speakers of vernacular language were $59 \%$, the Indonesian language was $40.8 \%$, foreign language is $0.2 \%$ [6]. Similar data is also given by a linguist who claims that Javanese is the largest ethnic group in Indonesia, around $50 \%$ of the national population [7]. Ten years later, the 1980 national census released that Javanese was spoken as the native language by $40.5 \%$ of the total population [7].

This finding also sheds light on the Javanese language maintenance. Social media applications, including Instagram are new media to bring the Javanese language in use. People can post and reply to their comment using Javanese. In addition, almost everyone has a mobile phone which provides communication media, e.g. WhatsApp, Line, and many others. People can instantly communicate with anyone. This has never happened in the past people communicate face to face or by phone.

As members of the world community, netizens of this account tries to use the world community's language that is
English beside their indigenous and national language. This finding allows netizens to manipulate three languages: Javanese, Indonesian, and English. The patterns of language are possible mixtures of these three languages. This is an evidence that Surabaya people have involved in the national and world community. As one of the netizens, for the latter case, wrote in his/her account in (12). S/he inserted English words into Javanese or Indonesian. S/he argued that “...the comment which is more qualified and can be accessed from abroad and home country" as in (14).

\section{(14) Pastinya lebih ingin comen yang lebih berbobot dan bisa dilihat dari luar dan dalam negeri.}

'Surely, I want to write the comment which is more qualified and can be accessed from abroad and home country.'

The use of English among netizens is reasonable as English has become the global language. Besides, English is very popular language in the world and the function of English language nowadays is widely changing. English functions as native, second, foreign language and also language as lingua franca is also growing [8]. In other words, English is also defined as expanding language because English has become a foreign language in many countries as well as in Indonesia [2]. Likewise, [9] English has become an international language due to the increasing numbers of countries in the world which make English has become as a special role, an official language, and a foreign language [9]. Statistically, there are 70 countries in the world which label English as the special status.

The use of English nowadays has led to the dynamic changes. Due to its position and its powerful, English is popular among people in Indonesia and they study English as second and foreign language. Despite the fact that English is popular language, English is also perceived as a language of developed western countries. English spreads easily all around the world through media such as television programs, popular music, movies and so on [2]. In addition, the wider space for using English in practice of interactive communication is through social media like e-mail, WhatsApp, Facebook, Instagram, and so the like.

Javanese world view is very influential and strongly shapes Indonesia's national landscape because of the domination of Javanese language in the society [7]. Javanese ethnic group is carrying along with their symbols of identity and it has spread throughout the archipelago and it also has created Javanese diaspora [7]. In the multilingual country like Indonesia, Javanese people commonly speak two languages: Javanese as their ethnic language and Indonesian as their national language. At present time, as everybody has a chance to be a part of the member of world community, English is also used in their communication regardless of the amount. This situation creates code mixing and leads to what so called a multilingual community as discussed in IVA.

This trend of using more than one language among netizens in "aslisuroboyo" account is plausible as Javanese is 
their ethnic language, Indonesian is their national language which everybody uses, and English as an international language that they have learned officially from junior high school. It is also the fact that English has blanketed their environments through exposures in community and media [10]. Thus, code mixing is unavoidable.

Code mixing is the use of the element of language in which "a mixing or combination of different variations within the same clause." [11]. For instance, the speaker mainly uses Indonesian but she or he inserts another language like the English language in order to look cool. Code mixing is divided into two, which are inner code mixing and outer code mixing [11]. Inner code mixing means mixed code derived from the original language with all its variations (formal, standard, informal, and non-standard). In contrast, outer code mixing means the speakers mix the code derived from foreign languages. It is acceptable to mix this code with the insertion of word, phrase, idiom, clause, and insertion from baster (combined forming native and foreign). to make it look cool [11]. This claim is proven by the netizens' opinion as addressed in section D.

Some other netizens have another view toward the use of code switching. The Javanese language is valued low language compare with English even though nobody uses English in daily communication. English is viewed as more prestigious due to the position as the international language [9] [2].

The use of more than one language is a reflection of the fact that Surabaya is a multilingual community. In this setting people have varieties of language use based on their need and motivation [12]; in other words, language choice happens in multilingual societies as they have more than two languages [13]. The proper choice of a language is salient [12]. Due to the wrong choice of language or variety, the goal of communication is not achieved and it would be in a disadvantageous position [13].

Another fact that the use of English among netizens is that they get used to using English for fixed technical terms which are not yet available in Indonesian and Javanese equivalent. The following in (15) and (16) are the examples. They used 'caption' and 'account' for they not only accustomed to using these words but also caption does not have its Indonesian and Javanese equivalent.

(15) Ojo lali mampir \& cek caption kulo nggeh.

'Don't forget to drop by \& check my caption, okay.'

(16) Yang mau di tag gak punya account sosmed. 'One who will be tagged doesn't have social media account.'

Another reason, sadly enough, some netizens confessed that Javanese language is difficult. This phenomenon was also detected among elementary students who reported that they did not use Javanese as they get difficulty in applying in their communication [14] and they were not accustomed to write in Javanese [7]

\section{Evidence of netizens' language-mixing levels}

Code mixing is classified into two categories: inner code mixing and outer code mixing. However, the data shows that the most frequent type applied is outer code mixing. In respect to the comments of Netizens in "aslisuroboyo" posts, the Javanese language is a matrix language and insertions of English are embedded in the grammatical structure of Javanese. Similarly, there was evidence that insertion of English words is in Indonesian structure. The patterns of mixing languages have been addressed in section $\mathrm{B}$ above. However, the English insertions can be classified into three, namely: lexical items or words, phrases, and clauses. The description of these levels is presented in turns as follows.

\section{1) Netizens' English insertion on word level}

There are 11 sentences which contain code mixing at the word level. The mixing can be Javanese and English (2 sentences), Indonesian and English (3 sentences), and Javanese-Indonesian-English (6 sentences).

An example of one English word insertion into Indonesian can be seen in (06). The matrix language is Indonesian, the word 'strong' is inserted. This adjective replaces Indonesian word kuat.

(06) Situ masih strong kan?

'Are you still strong, aren't you?'

Another example of one English word insertion is also found in Javanese structure, as seen in (07).

(07) Makane ajak kids jaman old kayak aku.

'That's why, invite the old era kids like me.'

The netizen employed English word 'kids' to substitute for Indonesian anak-anak, and s/he used 'old' for dulu. Interestingly, in this one Javanese sentence, there are two English words inserted. Yet, both of them are still on the word level.

The striking phenomenon is that a half of netizens' writing comments (6 out of 11 sentences) used three languages: Javanese-Indonesian-English with various structures. The brief discussion of this can be seen in (05) in Section IVB.

\section{2) Netizens' English insertion on phrase level}

The netizens' ability in using English comments in Javanese and Indonesian structure is not only on the word level but also on phrase level. There are eight sentences obtained from the comments of netizens to "aslisuroboyo" posts. They did code mixing at the phrase level. The patterns are, out of the total sentences, Javanese-English (6 sentences), Javanese-Indonesian, English (2 sentences), but no Indonesian-English mixing.

The netizen's comment as in (08) indicates that $\mathrm{s} / \mathrm{he}$ is able to use English well. Of five words in the sentence, three of them are in English. Two of English switching is realized in the phrasal expression 'take photo' which is equivalent to ambil foto in Inonesian or njupuk gambar/foto in Javanese. 
(08) Wonderful! Pengen take photo mrono.

'Wonderful! I want to take photo over there.'

Another phrasal expression is presented in (09). In this sentence, the netizen code mixed her/his writing in three languages. S/he might have used Javanese/Indonesian phrase ramah anak, however, s/he used English expression 'kids friendly' instead.

(09) Mak tempatnya kayaknya kids friendly nih.

'Wow the place/object looks kids friendly hey.'

\section{3) Netizens' English insertion on clause level}

Even though there are not many netizens who wrote the fully English comment of their posts in "aslisuroboyo" account, some of them used English on clause level. The mixing code of English clause is inserted into Javanese and Indonesian structures. This netizens' code switching on this level can be seen in (10) and (11).

(10) Inget banget itukan, first time I go with you. 'I remember that moment vividly, the first time I go with You.'

(11) Garai aku loro ati, Calo is full shit. 'It makes me hurt. Calo/Brooker is full shit.'

The two comments in (10) and (11) above share two things in common. The first, the netizens did code switching Indonesian-English and Javanese-English respectively on the clause level. The second, the English clause is embedded in the last part of the netizens' sentence writing.

In summary, even though Javanese is a dominant language use in the comments of "aslisuroboyo" account, many netizens do code switching to Indonesian and English. The way netizens did code switching is varying. Some of them inserted English words into the Javanese and Indonesian structure on the word level, some on the phrase level, and some others on the clause level. This finding suggests that the netizens may have good proficiency in English. This also indicates that English has been to be used in Javanese community. This initial remark may open a gap for further research.

\section{Netizens' reasons for using English}

SAside from the observation and documentation made by using Netnography, it is important to ask the question to the selected respondents regarding their use of English language in their comments on "aslisuroboyo" Instagram account. The netizens' responses are salient as to know their underlying reasons which may reflect their attitude towards Javanese as their ethnic as well as the community language and the other language in question.

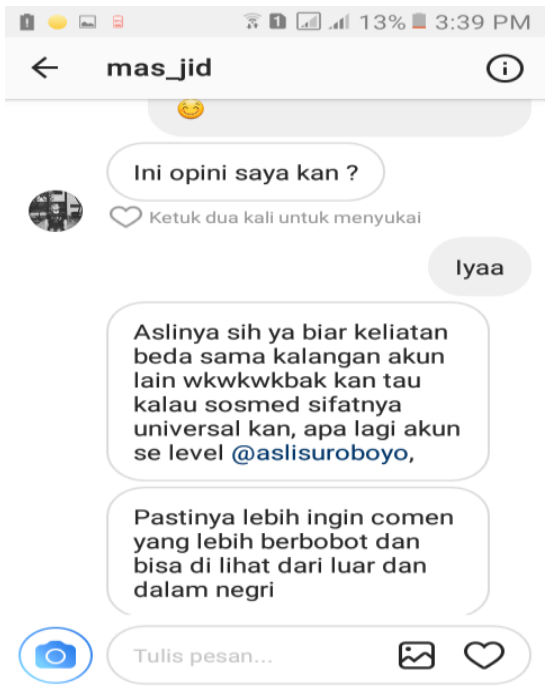

Fig.2. A Reason for Using English in Instagram

There are 21 respondents who were detected to do code switching in their comments. Then they were contacted and given questions. Yet, fifteen of them who were willing to give back their responses. The netizens have some reasons for the use of English in their comments. Almost half of the respondents ( 7 out of 15) claimed that it looks cool (keren) and prestigious (kelihatan beda/wah) when using English in their communication due to fact that the position of English is as the International language as seen from the screenshot in (12).

Some respondents confessed that they did code mixing unconsciously; it is like spontaneously expressed. Another reason is that they wanted to strengthen their skill in English; a kind of media for practice. Two respondents reported replied that they were accustomed to using English in their daily communication. There is one respondent who stated that $\mathrm{s} / \mathrm{he}$ code mixed into English as s/he got difficulty in using Javanese.

\section{E. Mixing languages and gender}

Studying the comments of "aslisuroboyo" posts, it seems that there is somewhat indicative of different language use among male and female netizens. It is found that female netizens have a tendency to mix languages more than female ones. During conducting this study, there were 21 participants who mixed their language. Of these total participants, 5 of them $(24 \%)$ are males whereas 16 of them $(76 \%)$ are females.

An interesting phenomenon of female language is seen in the comment. They seem to use mitigator, and one of them is seen in (13).

(13) Atur aja waktunya harus salah 1 orang dikapas off, maybe Nursari atau Juli off, baru bisa out bareng ciwiciwi.

'Set the time, one of them who are in Kapas should be off, maybe Nursari or Juli, then we can go out girls'

This female netizen used 'may be' which expresses uncertainty. Another similar expression is the use of 
'Wonderful!' as in (08). Unlike male, male netizens' expression seems to show their being independent and macho; to use swear word 'full shit' as in (11). These initial non-deep findings, however, should be followed by further comprehensive researches to support the possible bold statement.

Language use between male and female have been revealed by language sociologists and linguistic anthropologists. The results of the study of gender and the use of language demonstrate that men and women use language in different ways. It was found that women have a tendency to mix language while men have a tendency to use one language rather than mix the language [15]. Another study reveals that women mix language more due to the fact that women are more talkative and self-conscious than men [15]. Besides, women commonly use mitigators such as I think, may be, sort of and inessential qualifiers such as really happy, so beautiful [15]. This language makes women's speech expresses uncertain and powerless. While men are more independent and they frequently use swear words. This study also tries to identify as to whether there is different language use between men and women.

\section{CONCLUSION}

The Instagram of "aslisuroboyo" account was established by Surabaya people who claim themselves as Surabaya original. This is an iconic account as it resembles of Javanese ethnicity. As it is expected that Javanese is still dominantly used by netizens. This account functions as one of the media to help Javanese people maintain their identity through the use of their ethnic language. Besides the Javanese language, Indonesian is frequently used either by inserting words to Javanese structure or mixing alternatingly with Javanese sentence. This mixed language is reasonable as Indonesian is their national language.

The growing fast of social media triggers people to participate in global communication as part of the member of world community. In the Instagram of "aslisuroboyo" account, it is detected that netizens also used English in their posts. Then, the language used by netizens can be monolingual, bilingual, or multilingual. It means that the patterns can be either solely Javanese, Indonesian, or English; and also the possible mixtures of these three languages which are realized by netizens through the practice of code switching and code mixing.

The netizens used English in their Instagram comments are inspired by some different reasons. As English is an international language, they wanted to build communication internationally. Some confessed that they wanted to get prestige and to be cool. Some other claimed that it is a kind of habit and spontaneously expressed. A striking reason, even though not many citizens, is that they get difficulty in using the Javanese language. In addition, there is an initial phenomenon that language use between men and women is somewhat different. Women have a tendency to mix languages more than men.

\section{REFERENCES}

[1] Y. Hu, L. Manikonda, and S. Kambhampati, "What we Instagram : a first analysis of Instagram photo content and user types," Proc. Eight Int. AAAI Conf. Weblogs Soc. Media, pp. 595-598, 2014.

[2] D. Akynova, S. Zharkynbekova, A. Agmanova, A. Aimoldina, and L. Dalbergenova, "Language Choice Among the Youth of Kazakhstan: English as a Self-Representation of Prestige," Procedia - Soc. Behav. Sci., vol. 143, pp. 228-232, 2014.

[3] M. Ugot, "Language Choice , Mixing in Biase and Code-," vol. 8, no. 2, pp. 27-35, 2010.

[4] B. Ige, "Identity and language choice: 'We equals I," J. Pragmat., vol. 42, no. 11, pp. 3047-3054, 2010.

[5] Sorhaila Latip-Yusoph, "Language Trends in Social Media: Manifestations of Meranaws' Use of English on Facebook," USChina Foreign Lang., vol. 14, no. 7, pp. 480-490, 2016.

[6] P. W. J. Nababan, "Language in education: the case of indonesia," Int. Rev. Educ. -- Internationale Zeitschrifi ffir Erziehungswissenschafi -- Rev. Int. Pedagog., vol. 37, no. 1, pp. 115-131, 1991.

[7] S. Setiawan. (2001). Language Shift in a Bilingual Community: The Case of Javanese in Surabaya, East Java. The University of Auckland, New Zealand. Australia. MA Thesis.

[8] B. Issa and T. Al-Saleem, "Language and Identity in Social Net Working Sites," Int. J. Humanit. Soc. Sci., vol. 1, no. 19, pp. 197 202, 2011.

[9] R. Marlina, "The Pedagogy of English as an International Language," vol. 1, pp. 1-20, 2014.

[10] S. Setiawan. (2015). "Enemies" at Our Home: The Threat to Indigenous Languages Seen from Language Use. Proceeding International on Education Research and Education: Trends and Challenges Toward Asian Economic Community. Unesa. (689-705). http://icerd.unesa.ac.id

[11] S. -, M. Siregar, S. Bahri, and D. Sanjaya, "Code Switching and Code Mixing in Indonesia: Study in Sociolinguistics?," English Lang. Lit. Stud., vol. 4, no. 1, pp. 77-92, 2014.

[12] J. Clark and C. Yallop, An Introduction to Sociolinguistics Blackwell Textbooks in Linguistics. 2006.

[13] N. M. Awal, M. F. Jaafar, M. A. Mis, and H. Lateh, "Maintenance of Mother Tongue: Patterns of Language Choice at the MalaysianThai Border," Procedia - Soc. Behav. Sci., vol. 118, pp. 282-287, 2014.

[14] S. Setiawan, "Children's Language in a Bilingual Community in East Java," Sch. Humanit. Discip. Linguist. Univ. West. Aust., no. October, p. 502, 2013.

[15] K. Ahmed, I. Ali, and H. Xianfa, "Code-Mixing as a Marker of Gender Identity in SMS language in," vol. 20, no. 1, pp. 58-65, 2015 